\title{
Concept Map and Knowledge
}

\author{
AMM Sharif Ullah $\mathbb{B}$ \\ Division of Mechanical and Electrical Engineering, Kitami Institute of Technology, 165 Koen-cho, \\ Kitami 090-8507, Japan; ullah@mail.kitami-it.ac.jp; Tel./Fax: +81-157-26-9207
}

Received: 14 September 2020; Accepted: 14 September 2020; Published: 15 September 2020

Based on Piaget's genetic epistemology, Ausubel developed the assimilation theory of verbal learning [1,2]. This theory is considered the foundation of meaningful learning. The outcomes of meaningful learning take the form of concept maps-networks of some selected linguistic expressions and concepts [3]. Thus, concept map-based education helps avoid rote learning. Additionally, it helps prepare content for effective on-ground and e-learning. Moreover, it helps measure learning outcomes at the course, program, and institutional levels. As a result, concept map-based education has been used at school, college, university, and professional levels.

This Special Issue on Concept Mapping and Education solicited manuscripts on the theoretical foundations of concept mapping and its application areas, including (but not limited to) concept mapping in school, higher and professional education; concept mapping in active learning, problem-based learning, and project-based learning; and distance learning. Finally, this Special Issue published five selected articles, each of which went through a rigorous peer-review process. The editor would like to acknowledge the authors and reviewers for their invaluable contributions that enrich concept map-based education in particular and education science in general.

"A Concept Tree of Accounting Theory: (Re)Design for the Curriculum Development" [4] contributes to accounting and concept mapping literature by depicting a concept tree based on the Accounting Theory curriculum. The proposed tree-shaped concept map graphically interprets the sophisticated accounting theories and concepts and their complex interrelationships. In teaching practices, this concept tree promotes curriculum development, systematizing relevant topics, and exam-taking.

"Uncovering Types of Knowledge in Concept Maps" [5] uncovers the types of knowledge in concept maps. Concept maps represent different types of knowledge (e.g., procedural and conceptual). The authors used Legitimation Code Theory (LCT) to analyze concept maps in semantic gravity and semantic density. It was found that different types of knowledge are considered necessary to achieve professional knowledge or expert understanding. The author used examples to demonstrate students' learning patterns towards gaining expert knowledge. The authors described the implication of the study for curriculum design and teaching evaluation.

"The Salutogenic Management of Pedagogic Frailty: A Case of Educational Theory Development Using Concept Mapping" [6] reinterprets "pedagogic frailty" using concept maps, focusing on the salutogenesis of teachers such as assets, wellness, and sense of coherence. The concept maps define the complex relationship between pedagogic frailty and salutogenesis. This study paves the way to an educational theory for enhancing university-wide mental health literacy and avoiding the misapplication of existing teaching quality enhancement models. As a result, it has a greater utility for university managers.

"The Role and Efficacy of Creative Imagination in Concept Formation: A Study of Variables for Children in Primary School" [7] is a contribution towards creative concept formation, which is one of the main concerns of assimilation theory-based concept mapping. The 8-12-year-old school children were tested using four subtests. Three of the subtests were designed to evaluate narrative (verbal) 
creativity, and the other was designed to evaluate drawing (i.e., graphic) creativity. The tests indicate the child's learning ability regarding fluency, flexibility, originality in narrative representations, and graphics. The study can be used to evaluate concept map-based learning, focusing on creative thinking.

"Fundamental Issues of Concept Mapping Relevant to Discipline-Based Education: A Perspective of Manufacturing Engineering" [8] addresses some fundamental concept mapping issues relevant to discipline-based education (e.g., manufacturing education). This article argues that knowledge-type-aware concept mapping is a solution to create and analyze the semantic web-embedded dynamic knowledge bases for both human and machine learning from the perspective of Industry 4.0. Accordingly, this article defines five types of knowledge, namely, analytic a priori knowledge, synthetic a priori knowledge, synthetic a posteriori knowledge, meaningful knowledge, and skeptic knowledge. These types of knowledge help find some rules and guidelines to create and analyze concept maps for human and machine learning. The presence of these types of knowledge is elucidated using a real-life manufacturing knowledge representation case.

In sum, a problem cannot be solved without applying knowledge. Therefore, educators embark on how to disseminate knowledge to students. At the same time, students embark on how to learn relevant knowledge. Both knowledge dissemination and learning can be carryout using appropriately designed concept maps. In this case, the concept maps must manage the myriad proximal and distal relationships between knowledge and other relevant entities (human/machine learning, logical inferences, experimental data, analytical results, creative thinking, and cognitive reflections). As a result, knowledge-type-aware concept mapping is an effective means of education and learning [9]. Let us cherish this notion.

Funding: This research received no external funding.

Conflicts of Interest: The author declares no conflict of interest.

\section{References}

1. Ausubel, D.; Novak, J.; Hanesian, H. Educational Psychology: A Cognitive View, 2nd ed.; Holt, Rinehart \& Winston: New York, NY, USA, 1978.

2. Seel, N.M. Assimilation theory of learning. In Encyclopedia of the Sciences of Learning; Seel, N.M., Ed.; Springer: Boston, MA, USA, 2012. [CrossRef]

3. Novak, J.D. Learning, Creating, and Using Knowledge: Concept Maps as Facilitative Tools in Schools and Corporations, 2nd ed.; Rutledge: New York, NY, USA, 2012; p. 105644.

4. Zhou, Y. A Concept Tree of Accounting Theory: (Re)Design for the Curriculum Development. Educ. Sci. 2019, 9, 111. [CrossRef]

5. Kinchin, I.M.; Möllits, A.; Reiska, P. Uncovering Types of Knowledge in Concept Maps. Educ. Sci. 2019, 9, 131. [CrossRef]

6. Kinchin, I.M. The Salutogenic Management of Pedagogic Frailty: A Case of Educational Theory Development Using Concept Mapping. Educ. Sci. 2019, 9, 157. [CrossRef]

7. Gonzalez Garcia, J.; Mukhopadhyay, T.P. The Role and Efficacy of Creative Imagination in Concept Formation: A Study of Variables for Children in Primary School. Educ. Sci. 2019, 9, 175.

8. Ullah, A.S. Fundamental Issues of Concept Mapping Relevant to Discipline-Based Education: A Perspective of Manufacturing Engineering. Educ. Sci. 2019, 9, 228. [CrossRef]

9. Ullah, A.S. What is knowledge in Industry 4.0? Eng. Rep. 2020, 2, e12217. [CrossRef]

(C) 2020 by the author. Licensee MDPI, Basel, Switzerland. This article is an open access article distributed under the terms and conditions of the Creative Commons Attribution (CC BY) license (http://creativecommons.org/licenses/by/4.0/). 